九州大学学術情報リポジトリ

Kyushu University Institutional Repository

\title{
Mutagenicity and Anticholinesterase Activity of Some Possible Metabolites of Aryl N- Methy Lcarbamates
}

Eto, morifusa

Laboratory of Pesticide Chemistry, Faculty of Agriculture, Kyushu University

Kuwano, Ei ichi

Laboratory of Pesticide Chemistry, Faculty of Agriculture, Kyushu University

Yoshikawa, Mitsuko

Laboratory of Pesticide Chemistry, Faculty of Agriculture, Kyushu University

Suiko, Masahito

Laboratory of Biochemistry, Faculty of Agriculture, Miyazaki University

他

https://doi.org/10.5109/23751

出版情報: 九州大学大学院農学研究院紀要. 26 (4)，pp.213-219，1982-07. Kyushu University バージョン：

権利関係 : 


\title{
Mutagenicity and Anticholinesterase Activity of Some Possible Metabolites of Aryl N-Methylcarbamates
}

\author{
Morifusa Eto, Eiichi Kuwano and Mitsuko Yoshikawa \\ Laboratory of Pesticide Chemistry, Faculty of Agriculture, \\ Kyushu University 46-02, Fukuoka 812 \\ Masahito Suiko, Mitsuko Kohno, Mariko Kamihata \\ and Seiichiro Nakatsu \\ Laboratory of Biochemistry, Faculty of Agriculture, \\ Miyazaki University, Miyazaki 885 \\ (Received February 22, 1982)
}

\begin{abstract}
Some possible metabolites of carbaryl including demethyl, hydroxymethyl, $N$-hydroxy, and $N$-nitroso derivatives and of phenyl $N$-methylcarbamate were examined for mutagenicity using the mutants of Salmonellatyphimurium (Ames test) and $B a$ cillus subtilis (ret-assay). Only $N$-nitroso carbaryl showed mutagenicity in both the tests. However, the activity was diminished by rat-liver microsomal fraction (S-9). All the carbaryl derivatives had weaker anticholinesterase activity than the parent compound.
\end{abstract}

\section{INTRODUCTION}

Some non-hydrolytic metabolites of carbamate insecticides are known (Kuhr and Dorough, 1976). Particularly the modification of the' methylcarbamoyl moiety is of toxicological interest. N-Hydroxymethylcarbamate is one of the principal metabolites of carbaryl (Dorough and Casida, 1964) and is possibly an intermediate for $N$-demethylation, although this is not observed yet in methylcarbamate metabolism. Some $N$-hydroxy metabolites have been suggested to be biologically active principles of parent compounds as exemplified by the insecticide schradan (octamethylphosphorodiamidic anhydride) (O'Brien, 1960) and carcinogenic 2-acetylaminofluorene (Ivie and Bandal, 1981). Ethyl $N$-hydroxycarbamate has been known to be mutagenic (Koga et al., 1980). The metabolic formation of $N$-hydroxy carbaryl has been suggested (Locke, 1972), though not fully supported. Furthermore $\mathrm{N}$-nitrosocarbamates can be formed in the stomach in the presence of sodium nitrite, a food additive, and are known as potent mutagens (Blevins et al., 1977; Elespuru et al., 1974 ; Kawazoe et al., 1980).

The authors prepared the demethyl, hydroxymethyl, N-hydroxy, and $N$ nitroso derivatives of the insecticide carbaryl (1-naphthyl $N$-methylcarbamate) (I, $\mathrm{R}=\mathrm{NHCH}_{3}$ ) and of phenyl $\mathrm{N}$-methylcarbamate and examined for anticholinesterase activity and for mutagenicity towards some strains of $\mathrm{Sal}$ monella typhimurium and Bacillus subtilis. All the derivatives tested had weaker anticholinesterase activity than the parent compound and only $\mathrm{N}$-nitroso carbaryl showed the positive tests for mutagenicity. 


\section{MATERIALS AND METHODS}

\section{Chemicals}

1-Naphthyl N-methylcarbamate (carbaryl) and l-naphthyl carbamate were prepared in the usual methods.

Aryl $N$-hydroxymethylcarbamates were synthesized according to the method of Fukuto et al. (Fahmy and Fukuto, 1972). Naphthyl $N$-hydroxymethyl carbamate was prepared in $28 \%$ yield, $\mathrm{mp} 133-135^{\circ} \mathrm{C}$. Anal. Found: C, 66.25 ; $\mathrm{H}, 5.06 ; \mathrm{N}, 6.53$. Calcd. for $\mathrm{C}_{12} \mathrm{H}_{11} \mathrm{NO}_{3}: \mathrm{C}, 66.35 ; \mathrm{H}, 5.10 ; \mathrm{N}, 6.45 \%$. Phenyl $\mathrm{N}$-hydroxymethylcarbamate was prepared in $26 \%$ yield, mp $93-95^{\circ} \mathrm{C}$. Anal. Found: C, 57.43; H, 5.52; N, 8.43. Calcd. for $\mathrm{C}_{8} \mathrm{H}_{3} \mathrm{NO}_{3}: \mathrm{C}, 57.49 ; \mathrm{H}, 5.38: \mathrm{N}$, $8.38 \%$.

1 -Naphthyl $N$-hydroxy- $N$-methylcarbamate. To a cooled solution of $N$ methylhydroxylamine hydrochloride $(1.5 \mathrm{~g})$ and pyridine $(2.9 \mathrm{ml})$ in dichlorotnethane $(50 \mathrm{ml})$ was added dropwise with stirring naphthyl chloroformate $(3.7$ $\mathrm{g}$ ) in dichloromethane $(5 \mathrm{ml})$. The mixture was stirred for $1 \mathrm{hr}$ at $0-5^{\circ} \mathrm{C}$ and another $1 \mathrm{hr}$ at room temperature. It was then washed with water, dried and concentrated under reduced pressure. The residue was chromatographed on silica gel by elution with benzene and benzene-ether (1 :1). N-Hydroxy carbaryl was obtained from the benzene-ether eluate, $0.6 \mathrm{~g}(15.4 \%) \mathrm{mp}$ 93-95 ${ }^{\circ} \mathrm{C}$. NMR (CDCI,) $\delta: 3.38(3 \mathrm{H}, \mathrm{s}), 7.1-7.9(8 \mathrm{H}, \mathrm{m})$. IR $\nu_{\max }^{\mathrm{CHCl}_{3}}: 3100(\mathrm{OH})$, $1710(\mathrm{C}=\mathrm{O})$. Anal. Found: C, 66.63; H, 5.14; N, 6.42. Calcd. for $\mathrm{C}_{12} \mathrm{H}_{11} \mathrm{NO}_{3}$ : C, $66.35 ; \mathrm{H}, 5.10 ; \mathrm{N}, 6.45 \%$.

1-Phenyl N-hydroxy-N--methylcarbamate was prepared in $35 \%$ yield by the similar method. NMR $\left(\mathrm{CDCl}_{3}\right) \delta: 3.25(3 \mathrm{H}, \mathrm{s}), 6.8-7.3(6 \mathrm{H}, \mathrm{m})$. IR $\nu_{\max }^{\text {neat }}$ : $3250(\mathrm{OH}), 1720(\mathrm{C}=\mathrm{O})$. Anal. Found : C, $57.70 ; \mathrm{H}, 5.49 ; \mathrm{N}, 8.57$. Calcd. for $\mathrm{C}_{8} \mathrm{H}_{9} \mathrm{NO}_{3}: \mathrm{C}, 57.48 ; \mathrm{H}, 5.43 ; \mathrm{N}, 8.38 \%$.

1-Naphthyl N-nitroso-N-methylcarbamate. To a stirred mixture of naphthyl $\mathrm{N}$-methylcarbamate $(1 \mathrm{~g})$, acetic acid $(10 \mathrm{ml})$, and acetic anhydride $(50 \mathrm{ml})$ was slowly added sodium nitrite $(7.5 \mathrm{~g})$ taking $5 \mathrm{hr}$ at $0-5^{\circ} \mathrm{C}$. After kept overnight at $4^{\circ} \mathrm{C}$, the reaction mixture was poured into ice water and extracted with ether. The ether solution was washed with water, $5 \%$ sodium carbonate and brine, dried and concentrated under reduced pressure. The residue was recrystallized from hexane and ether to afford $0.8 \mathrm{~g}(69.6 \%)$ of $\mathrm{N}$-nitroso carbaryl, mp 65-67-C. NMR (CDCI,) 6: $3.32(3 \mathrm{H}, \mathrm{s}), 7.36-8.10(7 \mathrm{H}$, $\mathrm{m})$. IR $\nu_{\max }^{\mathrm{KBr}}: 1745(\mathrm{C}=\mathrm{O}), 1510(\mathrm{~N}=\mathrm{O})$. Anal. Found: C, 62.75; H, 4.39; N, 12.27. Calcd. for $\mathrm{C}_{12} \mathrm{H}_{10} \mathrm{~N}_{2} \mathrm{O}_{3}: \mathrm{C}, 62.60 ; \mathrm{H}, 4.35 ; \mathrm{N}, 12.17 \%$.

\section{Anticholinesterase assay}

The supernatant of lab-em-7-em housefly head homogenate in phosphate buffer ( $\mathrm{pH} 7.38)$ at $2000 \times \mathrm{g}$ centrifugation was used as an enzyme preparation. The residual enzyme activity after $10 \mathrm{~min}$ incubation with an inhibitor at $27^{\circ} \mathrm{C}$ was spectrometrically assayed by the Ellman method (Ellman et al., 1961) using acetylthiocholine as a substrate, dithiobisnitrobenzoic acid as a colorizing agent, and eserine sulfate for terminating the enzymic hydrolysis of the 
substrate.

\section{Ret-assay}

The assay method was essentially based on that described by Kada et al. (1972). Bacillus subtilis $\mathrm{H} 17 \mathrm{Rec}^{+}$and M45 $\mathrm{Rec}^{-}$were grown overnight in broth B--2 (10 g meat extract, $10 \mathrm{~g}$ yeast extract and $5 \mathrm{~g} \mathrm{NaCl}$ in $1000 \mathrm{ml}$ water, $\mathrm{pH}$ 7.0). The two cultures were streaked on the "dry" surface of a B-2 agar plate and the "starting points" were covered with a paper disk (12 mm diameter) containing $0.02 \mathrm{ml}$ solution of a test sample in dimethyl sulfoxide (DMSO). After kept for $25 \mathrm{hr}$ at $4^{\circ} \mathrm{C}$, the plates were incubated for $18 \mathrm{hr}$ at $37^{\circ} \mathbf{C}$ and the length of inhibition zone for each streak was measured.

\section{Reversion assay}

The assay was carried out as described by Ames et al. (1975) using two strains of Salmonella typhimuriun 'TA 100 and TA 98 which require histidine. The strain TA 100 is reversible by base-change type mutagens and TA98 is by flameshift mutagens. To a test-tube containing $2 \mathrm{ml}$ of molten top agar (0.7 \% agar, $0.6 \% \mathrm{NaCl}, 0.05 \mathrm{mM}$ histidine, $0.05 \mathrm{mM}$ biotin) were added 0.1 $\mathrm{ml}$ of a test chemical solution in DMSO, $0.1 \mathrm{ml}$ of an overnight culture of the bacteria and $0.5 \mathrm{ml}$ of sodium phosphate buffer ( $\mathrm{pH} \mathrm{7.4)}$ or the same buffer solution containing polychlorinated biphenyl (PCB)-induced rat liver homogenate (fraction S-9), $8 \mu$ mole $\mathrm{MgCl}_{2}, 33 \mu$ mole $\mathrm{KCl}, 5 \mu$ mole glucose 6 -phosphate, 0.5 unit glucose 6-phosphate dehydrogenase, $4 \mu$ mole NADPH. The tube contents were mixed and poured onto a plate containing $1.5 \%$ agar, $2 \%$ glucose and minimal salts. Histidine-revertant colonies were counted after incubation at $37^{\circ} \mathrm{C}$ for $48 \mathrm{hr}$.

\section{RESULTS AND DISCUSSION}

Table 1 shows the anticholinesterase activity of some carbaryl derivatives. The hydroxylation of the nitrogen atom and the methyl group decreases the activity. The N-hydroxy derivative is about 4-times less active than the parent compound, though Fukuto and his coworkers (Chiu et al., 1973) have reported that $m$-isopropylphenyl $N$-hydroxy- $N$-methylcarbamate is a reversible inhibitor of acetylcholinesterase (AChE) and its dissociation constant (Ka) for bovine erythrocyte AChE-inhibitor complex is 1800-times smaller than that of the corresponding N-methylcarbamate. Another hydroxylated meta. bolite, N-hydroxymethyl carbaryl, is about 500-times less active than carbaryl, supporting the finding of Dorough and Casida (1964). The N-nitroso derivative is also considerably less active as an anti-AChE agent; it is 160-times less active than the parent compound.

The mutagenicity screening of carbaryl and related compounds by the ret-assay showed only the N-nitroso carbaryl was active (Table 2). The demethyl and hydroxylated derivatives gave negative tests. Further examinations by the reversion assay on Salmonella typhimurium TA 100 supported 
Table 1. Anticholinesterase activity of some carbaryl derivatives (I).

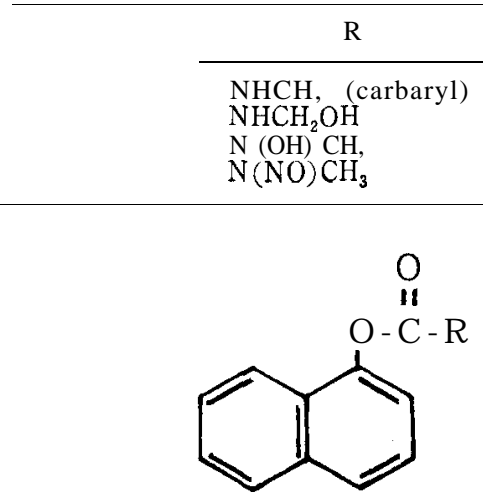

( I )

\begin{tabular}{l}
$\mathrm{I}_{50} \quad(\mathrm{M})$ \\
\hline $1.0 \times 10^{-7}$ \\
$5.0 \times 10^{-5}$ \\
$4.0 \times 10^{-7}$ \\
$1.6 \times 10^{-5}$ \\
\hline
\end{tabular}<smiles>[R]C(=O)Oc1ccccc1</smiles>

( I I )

those results as shown in Table 3. The carbaryl derivatives are much less active or rather negligible as mutagens in comparison with 4-nitroquinoline$N$-oxide (4-NQO), though they appear cytotoxic to this strain at the higher concentrations. Furthermore no increase in mutation frequencies was observ-

Table 2. Ret-assay of aryl carbamate derivatives I and II.

\begin{tabular}{|c|c|c|c|c|c|}
\hline \multirow[b]{2}{*}{ I } & Compound & \multirow{2}{*}{$\mu \mathrm{g} / \mathrm{disk}$} & \multicolumn{3}{|c|}{ Inhibition $(\mathbf{m ~ m})$} \\
\hline & $\mathrm{R}$ & & $\mathrm{H} 17 \mathrm{Rec}^{+}$ & M45 $\operatorname{Rec}^{-}$ & Difference \\
\hline 1 & $\begin{array}{c}\text { NHCH, } \\
\text { (carbaryl) }\end{array}$ & $\begin{array}{c}0.4 \\
4 \\
40 \\
400\end{array}$ & $\begin{array}{l}0 \\
0 \\
0 \\
0\end{array}$ & $\begin{array}{l}0 \\
0 \\
0 \\
0\end{array}$ & $\begin{array}{l}0 \\
0 \\
0 \\
0\end{array}$ \\
\hline I & $\mathrm{NH}_{2}$ & $\begin{array}{c}0.4 \\
4 \\
40\end{array}$ & $\begin{array}{l}0 \\
0 \\
0\end{array}$ & $\begin{array}{l}0 \\
0 \\
0\end{array}$ & $\begin{array}{l}0 \\
0 \\
0\end{array}$ \\
\hline I & $\mathrm{N}(\mathrm{OH}) \mathrm{CH}_{3}$ & $\begin{array}{c}0.4 \\
4 \\
40 \\
400\end{array}$ & & $\begin{array}{l}0 \\
0 \\
0 \\
0\end{array}$ & $\begin{array}{l}0 \\
0 \\
0 \\
0\end{array}$ \\
\hline I & $\mathrm{NHCH}_{2} \mathrm{OH}$ & $\begin{array}{c}0.4 \\
4 \\
40\end{array}$ & 0 & $\begin{array}{l}0 \\
0 \\
0\end{array}$ & $\begin{array}{l}0 \\
0 \\
0\end{array}$ \\
\hline I & $\mathrm{N}(\mathrm{NO}) \mathrm{CH}_{3}$ & $\begin{array}{c}0.4 \\
4 \\
40\end{array}$ & $\begin{array}{r}4 \\
11 \\
17\end{array}$ & $\begin{array}{r}9 \\
17 \\
41\end{array}$ & $\begin{array}{r}5 \\
6 \\
24\end{array}$ \\
\hline II & $\mathrm{N}(\mathrm{OH}) \mathrm{CH}_{3}$ & $\begin{array}{c}0.4 \\
4 \\
40 \\
400\end{array}$ & $\begin{array}{l}0 \\
0 \\
0 \\
0\end{array}$ & $\begin{array}{l}0 \\
0 \\
0 \\
0\end{array}$ & $\begin{array}{l}0 \\
0 \\
0 \\
0\end{array}$ \\
\hline II & $\mathrm{NHCH}_{2} \mathrm{OH}$ & $\begin{array}{c}0.4 \\
4 \\
40\end{array}$ & $\begin{array}{l}0 \\
0 \\
0\end{array}$ & $\begin{array}{l}0 \\
0 \\
0\end{array}$ & $\begin{array}{l}0 \\
0 \\
0\end{array}$ \\
\hline $4-\mathrm{NQ}$ & & $\begin{array}{l}0.4 \\
4\end{array}$ & $\begin{array}{l}1 \\
6\end{array}$ & $\begin{array}{r}6 \\
15\end{array}$ & $\begin{array}{l}5 \\
9\end{array}$ \\
\hline
\end{tabular}


ed after metabolic activation by PCB-induced rat liver homogenate S-9. Of the tested derivatives $\mathrm{N}$-nitroso carbaryl appears the most active mutagen. The mutagenicity of $\mathrm{N}$-nitroso carbaryl has been reported in some bacterial systems including Escherichia coli, Haemophilus infuenzae, and SaImonella typhimurium TA 1538 (Elespuru et al., 1974; Egert and Greim, 1976).

Table 3. Mutagenicity test of carbaryl and related compounds (I) on Salmonella typhimurium TA100.

\begin{tabular}{|c|c|c|c|}
\hline \multirow{2}{*}{$\begin{array}{c}\text { Compound } \\
\text { R }\end{array}$} & \multirow{2}{*}{ fig/plate } & \multicolumn{2}{|c|}{ His+ revertants/plate* } \\
\hline & & without S-9 & with S-9 \\
\hline $\mathrm{NHCH}$, (carbaryl) & $\begin{array}{l}0.2 \\
2 \\
20\end{array}$ & $\begin{array}{l}40 \\
22 \\
33\end{array}$ & $\frac{-}{3}$ \\
\hline $\mathrm{NH}_{2}$ & $\begin{array}{l}0.2 \\
2 \\
20\end{array}$ & $\begin{array}{r}9 \\
22 \\
20\end{array}$ & $\overline{16}$ \\
\hline $\mathrm{N}(\mathrm{OH}) \mathrm{CH}_{3}$ & $\begin{array}{l}0.2 \\
2 \\
20\end{array}$ & $\begin{array}{l}57 \\
18 \\
46\end{array}$ & $\overline{10}$ \\
\hline $\mathrm{NHCH}_{2} \mathrm{OH}$ & $\begin{array}{c}0.2 \\
2 \\
20\end{array}$ & $\begin{array}{l}26 \\
33 \\
15\end{array}$ & $\overline{15}$ \\
\hline $\mathrm{N}(\mathrm{NO}) \mathrm{CH}_{3}$ & $\begin{array}{l}0.02 \\
0.2 \\
2\end{array}$ & $\begin{array}{l}43 \\
39 \\
35\end{array}$ & $\frac{-}{9}$ \\
\hline 4-NQO & 0.2 & $220-267$ & - \\
\hline $\mathrm{AAF}^{* *}$ & 50 & - & $44-210$ \\
\hline
\end{tabular}

* The numbers of spontaneous revertants (5 to 40 without S-9 and 76 to 103 with S-9) have been subtracted from the experimental values.

** 2-Acetylaminofluorene.

Shirasu et al. (1976) have demonstrated the ret-assay is a convenient and reliable screening method for the mutagenicity of pesticides, surveying 166 pesticides. They also showed carbaryl gave a negative test on the ret-assay. Brevin et al. (1977) suggested that carbaryl was nonmutagenic on Salmonella even after the addition of rat liver microsomal suspension. The data presented here also indicate that at least the possible modifications of the carbamoyl moiety by microsomal monoxygenase do not raise any base-change type mutagens from carbaryl. Egert and Greim (1976) have, however, reported that the mutagenicity of carbaryl on S. typhimurium TA 1538, which is reversible by flameshift mutagens, is increased after metabolic activation by mouse liver microsomes. They also suggested that $\mathrm{N}$-nitroso carbaryl was activated by the action of microsomes. On the contrary, we found the mutagenicity of $N$ nitroso carbaryl on S. typhimurium TA 100, which is reversible by base-change mutagens, was diminished by the addition of PCB-induced rat liver S-9 fraction (Table 3). Moreover no carbaryl derivatives tested here gave positive tests on another strain TA 98, which is reversible by flameshift mutagens.

In conclusion, carbaryl is non-mutagenic even after the metabolic trans- 
formation of the carbaryl moiety. The oxidative biotransformation is regarded as one of detoxication processes: Although the $N$-hydroxy derivative has a considerable anti-AChE activity, it is rarely found as the metabolite; the $N$-methylol derivative appears toxicologically inactive. The $N$-nitroso derivative is mutagenic, but can be detoxified by metabolism and the possibility of its formation in the environment and in the body may be practically negligible.

\section{ACKNOWLEDGEMENT}

This work was supported partially by Grant-in-Aid for Scientific Research from the Ministry of Education, Science and Culture of Japan. We thank Professor H. Omura for the supply of the bacterial strains.

\section{REFERENCES}

Ames, B. N., J. McCann and E. Yamasaki 1975 Methods for detecting carcinogens and mutagens with the Salmonella/mammalian-microsome mutagenicity test. Mutat.Res., 31: 347-364

Blevins, R. D., M. Lee and J. D. Regan 1977 Mutagenicity screening of five methyl carbamate insecticides and their nitroso derivatives using mutants of Salmonella typhimurium LT2. Mutat. Res., 56: 1-6

Chiu. Y. C., M. A. H. Fahmy and T. R. Fukuto 1973 Aryl N-hydroxy- and N-methoxy-Nmethylcarbamates as potent reversible inhibitors of acetylcholinesterase. Pest. Biochem. Physiol., 3 : 1-6

Dorough, H. W. and J. E. Casida 1964 Nature of certain carbamate metabolites of the insecticide Sevin. J.Agric. Food Chem., 12: 294-304

Egert, G. and H. Greim 1976 Formation of. mutagenic N-nitroso compounds from the pesticides prometryne, dodine and carbaryl in the presence of nitrite at $\mathrm{pH}$. Mutat. Res., 37: 179-186

Elespuru, R., W. Lijinsky and J. K. Setlow 1974 Nitrosocarbaryl as a potent mutagen of environmental significance. Nature. $247: 386-387$

Ellman, G. L., K. D. Courtney, V. Andres, Jr. and R. M. Featherstone 1961 A new and rapid colorimetric determination of acetylcholinesterase activity. Biochem. Pharmacol., 1: $88-95$

Fahmy, M. A. H. and T. R. Fukuto 1972 Convenient method for synthesis of hydroxymethylcarbamates. J.Agric. Food Chem., 20: 168-169

Ivie, G. W. and S. K. Bandal 1981 Metabolic aspects of pesticide toxicology. In "The Pesticide Chemist and Modern Toxicology," ed. by S. K. Bandal, G. J. Marco, L. Golberg and M. L. Leng, ACS Symposium Series 160, Am. Chem. Soc., Washington, D.C.. pp. 257-284

Kada, T., K. Tutikawa and Y. Sadaie 1972 In vitro and host-mediated ret-assay procedures for screening chemical mutagens and phloxine, a mutagenic red dye detected. Mutat. Res., 16: 165-174

Kawazoe, Y., H. Koga, K. Tatsumi and T. Horiuchi 1980 Nitrosation of ethyl carbamate: Isolation of ethyl N-ethyl-N-nitrosocarbamate. Chem. Pharm. Bull., 28: 3447-3448

Koga, H., Y. Kawazoe. K. Tatsumi and T. Horiuchi 1980 The mutagenic activity of ethyl N-hydroxycarbamate and its related compounds in Salmonella typhimurium. Mutat. Res., 78: $145-150$ 
Kuhr, R. J. and H. W. Dorough 1976 Carbamate Insecticides : Chemistry. Biochemistry and Toxicology. CRC Press, Cleveland

Locke, R. K. 1972 Thin-layer chromatography of 1-naphthyl $N$-hydroxy, $N$-methylcarbamate and its application in two in vitro studies involving carbaryl. J.Agric. Food Chem., 20 : 1078-1080

O’Brien, R. D. 1960 Toxic Phosphorus Esters. Academic Press, New York

Shirasu, Y., M. Moriya. K. Kato, A. Furuhashi and T. Kada 1976 Mutagenicity screening of pesticides in the microbia! system. Mutat. Res., 40: 19-30 